\title{
Water Contamination by Heavy Metals and their Toxic Effect on Aquaculture and Human Health through Food Chain
}

\author{
Swaroop S Sonone ${ }^{1(\mathbb{D})}$, Swapnali Jadhav ${ }^{2} \mathbb{D}$, Mahipal Singh Sankhla ${ }^{3, *(\mathbb{D})}$, Rajeev Kumar ${ }^{4}(\mathbb{D}$ \\ 1 M.Sc. Forensic Science, Government Institute of Forensic Science, Aurangabad, Maharashtra, India; \\ sononeswap4@gmail.com (S.S.S.); \\ 2 Msc. Forensic Science, Government Institute of Forensic Science, Aurangabad, Maharashtra, India; \\ jadhavswapnali6760@gmail.com (S.J.); \\ 3 Research Scholar, Department of Forensic Science, School of Basic and Applied Sciences, Galgotias University, Greater \\ Noida, India; mahipal4n6@gmail.com (M.S.S.); \\ 4 Associate Professor, Department of Forensic Science, School of Basic and Applied Sciences, Galgotias University, Greater \\ Noida, India; rajeev4n6@gmail.com (R.K.); \\ * Correspondence: mahipal4n6@gmail.com;
}

Received: 10.09.2020; Revised: 15.10.2020; Accepted: 17.10.2020; Published: 21.10.2020

\begin{abstract}
Heavy metals are metals with relatively high density and toxic at very low concentrations. The common heavy metal pollutants can be traced everywhere in minimal quantities. Heavy metals contaminate aquatic environments through various sources like industrial waste, domestic effluents, atmospheric sources, and other metal-based industries, E-Waste. Aquaculture is the rearing of aquatic animals and other organisms. Heavy metal toxicity is responsible for the degradation of the population of aquaculture, causing physical deformities in organisms and polluting the aquatic environment. These toxic heavy metals cause various diseases in fishes. As fishes are part of human consumption, it is indirectly affecting humans also. The food chain is greatly impacted by the introduction of heavy metals in water bodies \& aquatic ecosystems. These heavy metals have greater significance on the environment as they persist for longer durations and have bioaccumulative capacities causing degradation of water health.
\end{abstract}

Keywords: aquaculture; heavy metal; toxicity; fish; ecosystem; water; health.

(C) 2020 by the authors. This article is an open-access article distributed under the terms and conditions of the Creative Commons Attribution (CC BY) license (https://creativecommons.org/licenses/by/4.0/).

\section{Introduction}

Heavy metals are any metallic element that has high density and are toxic even at lower amounts [1]. Some of the common heavy metals are mercury, lead, arsenic, chromium, cadmium, thallium, etc. These are also known as trace elements, e.g., zinc, copper, and selenium. These heavy metals are necessary to maintain body metabolism but are toxic to the body when they are present in higher concentrations. Sources of heavy metals in the bodies are entered through food, air, and drinking water [2]. There are different ways for these metals to get deposited into the aquatic environment like various natural and anthropogenic sources, through industrial and domestic sewage, leaching from landfills, storm runoff, shipping, and harbor activities and atmosphere also [3,4]. Metals have a bioaccumulative nature. Bioaccumulation means the accumulation over time of a substance and especially a contaminant (such as a pesticide or heavy metal) in a living organism. Such compounds in living things are stored at a faster rate and are not easy to metabolize or excrete [5]. The excess 
quantities of heavy metals are detrimental as these destabilize the ecosystems because of their bioaccumulation in organisms and elicit toxic effects on biota and even death in most living organisms [6]. The contaminants of metals remain either insoluble or suspension form in aquatic systems. These contaminants descend at the bottom or are carried by aquatic organisms [7]. Heavy metal toxicity in aquatic organisms is greatly affected by several factors, including alkalinity, hardness, $\mathrm{pH}$, dissolved oxygen, temperature, and turbidity [8]. The $\mathrm{pH}$ of an aquatic environment influences heavy metal speciation. It also affects the physiology of aquatic biota, which in turn can modify the susceptibility of these organisms to heavy metals [9]. Fishes are broadly used for the evaluation of the well-being of aquatic ecosystems. Pollutants in the food chain are accountable for unfavorable effects and death in aquaculture [10]. Fishes cannot flee from the harmful effects of these pollutants among aquatic organisms. Thus growth, health, survival, and development of these fishes are affected [11]. Heavy metals are potent neurotoxins in fishes. The synergy of heavy metals with biochemical inducements in fish may prevent the communication of fish with their surroundings [12]. Fishes are the major source of vitamins, protein, polyunsaturated fatty acids, and minerals that are eaten by human beings. These heavy metals in the aquaculture can cause diseases like Minamata (Organic Mercury Poisoning). The bioaccumulation of Heavy metals may pose great hazards to the health of humans and animals that rely on water bodies $[5,13]$.

\section{Sources of heavy metal contamination in aquatic environment}

Heavy metals in surface water systems can come from natural or anthropogenic sources. Geological/natural sources include volcanic eruptions, weathering of metal-containing rocks, sea-salt sprays, forest fires, natural weathering processes that can commence to the discharge of metals from their endemic skies to different environmental sections. Hydroxides, oxides, sulfides, sulfates, phosphates, silicates, and organic compounds are some of the forms in which heavy metals can be found out $[14,15]$.

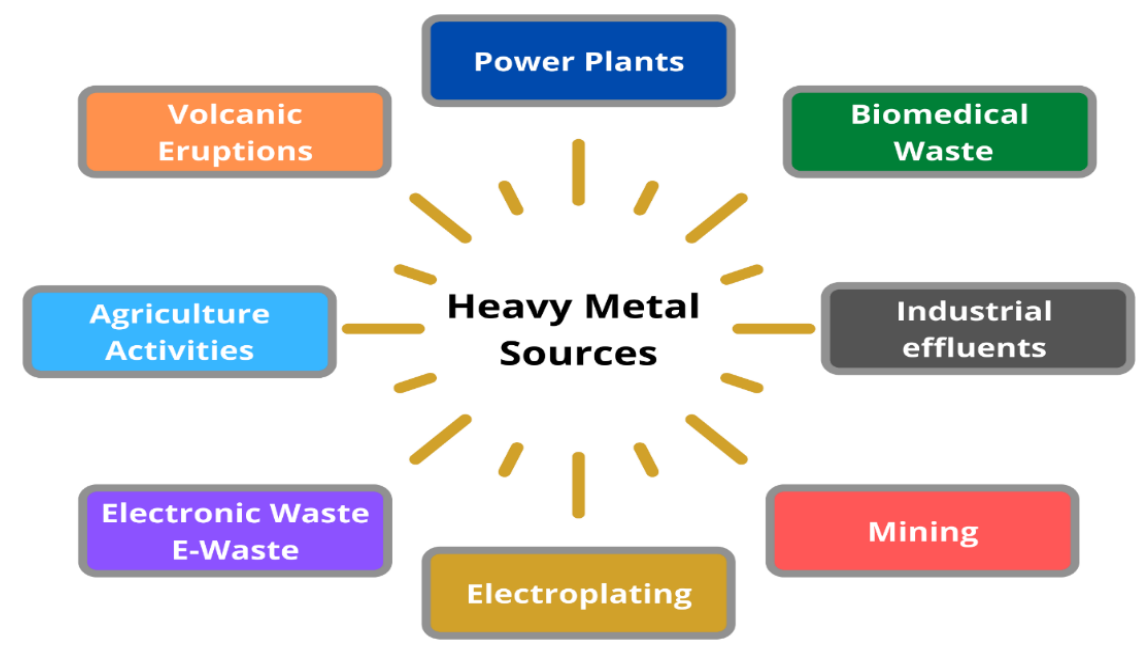

Figure 1. Diffrent sources of contamination heavy metal in water \& aquaculture.

\subsection{Volcanic eruptions.}

Volcanic ash is the most widely-distributed product of explosive volcanic eruptions, and areas hundreds of kilometers distant from an erupting volcano can receive ash falls. Even minor quantities of ash can disrupt the water system [16]. Volcanic ash falls on the water 
system causing water contamination with turbidity, acidification, and low $\mathrm{pH}$. Surface coatings on fresh volcanic ash are highly acidic due to the influence in the plume of aerosols composed of the strong mineral acids $\mathrm{H} 2 \mathrm{SO} 4, \mathrm{HCl}$ and $\mathrm{HF}$. Therefore, when freshly-erupted ash comes into contact with water, it has the potential to lower the $\mathrm{pH}$ beyond acceptable limits for the protection of aquatic life [17]. Global inclinations of industrialization and urbanization have led to accession in the anthropogenic portion of heavy metals in the atmosphere [18]. Common anthropogenic origins of heavy metals are mining, smelting, power plant waste, industrial and agricultural activities. Certain metals are discharged during mining and extraction of various elements from their ores. Dry and wet deposition is responsible for heavy metals discharged to the atmosphere through mining, smelting, and other industrial processes. Discharge of wastewaters such as manufacturing effluents and domestic excrement supplement heavy metals to the environment [19]. Anthropogenic methods of heavy metals have been recorded to went ahead than the natural fluxes. Elements generally emitted in wind-blown dust are frequently from industrialized zones. Some major causes which significantly contribute to the heavy metal pollution in the surroundings comprise vehicle exhaust, which discharges lead; smelting, which frees arsenic, copper, and zinc; insecticides that liberate arsenic and burning of fossil fuels which release nickel, vanadium, mercury, selenium, and tin. Individual actions add more to environmental deterioration due to the daily production of assets to match the desires of the huge community [20].

\subsection{Industrial effluents.}

Municipal waste, domestic sewage, industrial waste directly discharged into the natural water system are some of the major causes of pollution. Untreated waste discharge leads to water contamination. The major source of contamination of surface and groundwater water is the discharge of manufacturing effluents without treatment inside the water bodies [21]. Wastewater, which comprises several microorganisms, heavy metals, nutrients, radionuclides, pharmaceutical, and personal care products, all find their way to surface water resources causing irreversible damage to the aquatic ecosystem and to humans as the aesthetic value of such water is compromised. These pollutants decrease the supply of usable water, increase the cost of purifying it, contaminate aquatic resources, and affect food supplies [22]. Pollutants like acid, a toxic metal, agrochemicals, dyes, and other untreated waste discharged from industries cause water pollution. Discharged products which often result in pollution, also results in loss of biodiversity in the aquatic ecosystem, and do also cause possible health risks related to cholera, diarrhea, etc., in humans.

\subsection{Agriculture activities.}

Agricultural systems have expanded and intensified in response to the ever-increasing demand for food. The overuse and misuse of agrochemicals, water, animal feeds, and drugs designed to increase productivity have resulted in higher pollution loads in the environment, including rivers, lakes, aquifers, and coastal waters. Aquatic ecosystems are also affected by agricultural pollution; for example, eutrophication caused by the accumulation of nutrients in lakes and coastal waters has impacts on biodiversity and fisheries. Agricultural systems have expanded and intensified in response to the ever-increasing demand for food [23]. Farms discharge large quantities of agrochemicals, organic matter, drug residues, sediments, and saline drainage into water bodies. The resultant water pollution poses demonstrated risks to 
aquatic ecosystems, human health, and productive activities [24]. Agricultural Waste released into aquatic habitats has led to several deleterious effects on aquatic organisms, including fish, concentrates pollutants right from polluted water, and lengthily through the food chain. Insecticides, herbicides, and fungicides are applied intensively in agriculture in many countries. When improperly selected and managed, they can pollute water resources with carcinogens and other toxic substances that can affect humans [25].

\subsection{Mining.}

Environmental pollution by heavy metals is very prominent in areas of mining and old mine sites, and pollution reduces with increasing distance away from mining sites [26]. Mining is the extraction of minerals and other geological material from deposits of earth. Mining Industry works to extract the metals and minerals that our society needs for agriculture, housing, music, telecommunication, the environmental industry, construction, space exploration, and medicines. Water pollution is a major concern for mining activity [27]. Large amounts of water produced from mine drainage, mine cooling, aqueous extraction, and other mining processes increases the potential for these chemicals to contaminate ground and surface water. Surface water is principally degraded by various factors like an accidental spill of toxic chemicals, erosion of waste material, or discharging of contaminant water from mines [28].

\subsection{Electroplating.}

Electroplating is a plating method that utilizes electrical flow to decrease cations of a coveted substance from a solution and coat a conductive gadget with a thin layer of the material, such as a metal. It is principally employed for dropping a layer of metal below the desired part (e.g., abrasion and wear resistance, corrosion protection, lubricity, aesthetic qualities, etc.) to a surface that otherwise lacks that property. Electroplating industries effluent contaminate air, water, and soil. Electroplating is a major polluting industry because it discharges toxic materials and heavy metals through water, air emissions, and solid waste in an environment that various processing industries have reported containing high amounts of heavy metals such as nickel, iron, lead, zinc, chromium, cadmium and copper [5, 29].

\subsection{Electronic waste/E-waste.}

The uncontrolled dumping and inappropriate recycling of e-waste pose serious threats to human health and the environment at large [30]. The toxic chemicals that exist in e-waste include a wide range of heavy metals, such as lead $(\mathrm{Pb})$, cadmium $(\mathrm{Cd})$, mercury $(\mathrm{Hg})$, arsenic (As), and nickel (Ni), and also persistent organic compounds, such as brominated flame retardants (BFRs) and phthalates. Other chemicals that appear in e-waste include polychlorinated biphenyls (PCBs), nonylphenol (NP), and triphenyl phosphate (TPPs), among others [31]. E-wastes are the known major source of heavy metals, hazardous chemicals, and carcinogens. Certain diseases related to skin, respiratory, intestinal, immune, and endocrine and nervous systems, including cancers, can be prevented by proper management and disposal of E-waste. With a view to bridging the digital divide, there is exponential growth in the use of Electrical and electronic equipment (EEE), and so there is an alarming effect on the environment and human health when the ICT wastes are not disposed of scientifically. There is an emergent need to implement the existing policies and guidelines in line with the international standards and practices for a healthy E-waste management system [32]. 


\subsection{Biomedical waste.}

Medical waste contains body parts, organs, tissues, blood, and body fluids along with soiled linen, cotton, bandage, and plaster casts from infected and contaminated areas along with used needles, syringes, and other sharps. It contains pathogens in mass, in their invisible forms. Water pollution can also be caused due to biological, chemical, and radioactive substances. Leaching out of pathogens can pollute the water and may cause diseases. Heavy metals present in a chemical waste can also cause water pollution. They can enter into biological systems through the process of biological magnification. Pollution of water bodies can alter parameters such as $\mathrm{pH}, \mathrm{BOD}, \mathrm{DO}, \mathrm{COD}$, etc. and may further become toxic for flora and fauna of the water body [33]. The improper disposal of biomedical waste may have a negative impact on the water quality as different pollutants may leach out from the waste dumping sites into the groundwater. Biomedical waste contains a high concentration of heavy metals and polycyclic aromatic hydrocarbons (PAHs), and results in unfavorable amounts of hazardous materials and may pollute surface and groundwater [34].

\subsection{Power plants.}

Nuclear and fossil fuel plants produce significant thermal pollution to bodies of water. Thermal water pollution is the degradation of water quality due to a change in ambient water temperature [35]. According to the Environmental Protection Agency (EPA), thermoelectric power plants alone contribute 50 percent to 60 percent of all toxic pollutants discharged to surface waters by all industrial categories under the Clean Water Act (CWA) [36]. Among the various types of thermoelectric generating units, coal-fired plants are the biggest source of that toxic pollution. Out of the 1,100 steam-electric facilities currently operating in the United States, about half are coal-fired power plants. Every year, these plants dump millions of tons of toxic heavy metals such as arsenic, selenium, lead, mercury, boron, and cadmium into waterways across the nation [36,37]. Multiple issues occur concurrently when heated water is released into an aquatic ecosystem. The most immediate change is a decrease in dissolved oxygen levels and a rise in $\mathrm{pH}$. Warm water cannot hold as much dissolved oxygen as cold water, and organic matter decomposes faster in warmer temperatures. The increase in decomposed aqueous nutrient concentrations causes eutrophication, most commonly realized as algae blooms, which block sunlight for underlying aquatic plants. The abundance of algae is an easy food source for aerobic microbes that soar in the population and further deplete the dissolved oxygen. Low oxygen levels create hypoxic dead zones that cannot support most aquatic organisms [38, 39]. Additionally, rapidly heated water accelerates the metabolism of cold-blooded aquatic animals like fish, causing malnutrition due to insufficient food sources. Since the environment usually becomes more inhospitable to the area's aquatic fauna, many species leave while more vulnerable species may die, changing the biodiversity of both the original and invaded locations. These effects are especially dramatic near coral reefs, the home of over 2 million aquatic species and roughly $25 \%$ of all marine life [40].

\section{Effect of heavy metal on aquatic environment \& aquatic health}

Unlike organic chemicals, the majority of metals cannot be merely metabolized into less toxic compounds, a characteristic of them being the death of biodegradability. Once introduced into the aquatic setting, metals are redistributed throughout the water column, accumulated in sediments, or consumed by aggregation [41]. Because of the activity and 
remobilization processes of metals, the sediments represent a semi-permanent offer of contamination to the natural phenomenon. Metal residues in contaminated habitats have the flexibleness to bioaccumulate in aquatic ecosystems - aquatic flora and fauna [42], which, in turn, would possibly enter into the natural human phenomenon and result in health problems [43]. Metal accumulation in sediments happens through processes of precipitation of positive compounds, binding fine solid particles, association with organic molecules, co-precipitation with metal or Mn oxides or species delimited as carbonates - according to the physical and chemical conditions existing between the sediment and conjointly the associated water column [44, 45]. Metal bioavailability is made public as a result of the fraction of the general concentration of the metal that has the potential to accumulate at intervals in the body. The factors that management the bioavailability of metals are the following: the organism biology (metals assimilation efficiency, feeding ways, size or age, generative stage); metal natural science (distribution in water - sediment, suspended matters, and metal speciation) [46, 47]; physical and chemical factors (temperature, salinity, $\mathrm{pH}$, ionic strength, the concentration of dissolved organic carbon, total suspended solids) [48, 49]. Metal bioavailability controls their accumulation in aquatic organisms. The metals up taken ways are through the receptive stratum if metals are in dissolved forms or through the food intake if metals are in particulate forms. Metal biological processes, the presence of organic or inorganic complexes, $\mathrm{pH}$, temperature, salinity, and reaction conditions [50] are the foremost factors that will modulate metal toxicity. The intake uptake depends on similar factors, and therefore the speed of feeding, enteral transit time, and conjointly the digestion efficiency [51]. Many studies have shown that the free hydrated metallic particle is the foremost bioavailable sort for metal, $\mathrm{Cd}, \mathrm{Zn}$ [52], and elements [53], but some exceptions are reported [54]. Thus, the importance of different chemical kinds of dissolved metals and complexes designed with applicable organic ligands with low relative molecular mass shouldn't be neglected. It has been found that the presence of organic binders can increase the bioavailability of $\mathrm{Cd}$ in mussels and fish by facilitating the diffusion of the hydrophobic compound at intervals in the lipid membrane. The organic compounds of metals are also further bioavailable than the ionic forms [55]. The mercurial organic compounds are macromolecules-soluble and penetrate the lipid membranes quickly, increasing the toxicity compared to corrosive sublimate that won't lipid-soluble [56]. The action on suspended solids affects the general concentration of metals gifts in water. The association between solid particles and metals is also important for the metal uptake into organisms through food intake [57]. The suspended solids accumulate the insoluble metal compounds, but beneath positive conditions, the metal reaches the gap water being dissolved. Important metal concentrations from sediments or suspended solids are loads of over in the water, so a tiny low fraction of them is also a really necessary offer for bioaccumulation in organisms and benthic organisms [58]. The dynamics of varied kinds of metals at intervals in the aquatic setting are not all understood, so new studies are required to research the varied accumulation/bioaccumulation pathways supported by dissolved or suspended metal forms. Different studies highlighted that bioavailability of metals in bivalve mollusks depends on sediment particle size because of their filter-feeding behavior. If the particles were coated with living things, polymers, or fulvic acids, the $\mathrm{Cd}, \mathrm{Zn}$, and $\mathrm{Ag}$ bioavailability were significantly exaggerated. Overall, the binding of metal reduced the bioavailability of metals from the sediment $[54,59]$. Both freshwater and marine ecosystems are endangered by pollution. The decomposition of water sources by heavy metals is a notable environmental concern that unfavorably affects plants, animals, and human health. Freshwater fish are manifested to several toxic heavy metals discharged to water bodies from 
various sources. Pollution of aquaculture by heavy metals has heightened an extensive global point because it exhibits a threat to fish and has health risks to fish buyers [60].

\subsection{Effect of heavy metal on aquaculture.}

The major source of water pollution is heavy metals, as it annihilates the economically prestigious species either indirectly through dissecting the biological chain or directly affects toxic strain through chemical modifications in water [61]. Heavy metals enter fish bodies in three potential ways: by gills, by the body surface, and by the digestive tract. Immediate uptake of metals from the water is done by gills $[62,63]$, while the body surface is normally guessed to take a lesser part in the uptake of these elements in fish [64]. Concentrations of metals in tissues thus cause many biochemical, physiological, and histological alterations in the fishes and other freshwater fauna by changing the activities of various enzymes and metabolites [65]. Fish is one of the universally distributed organisms in the aquatic ecosystem, and being receptive to metal poisoning may display the amount of the biological effect of metal pollution in waters [66]. The process of uptake in fish is peculiar in diverse species according to varied factors, i.e., the developmental, psychical agents, and the lifetime of the fish [67]. Fish inhabiting contaminated waters conduct to store heavy metals in their tissues. Usually, collection depends on metal intensity, duration of expression, way of metal uptake, environmental circumstances (temperature, $\mathrm{pH}$, hardness, salinity), and inherent agents such as fish age and feeding habits. Many metals present varying magnetization to fish tissues. Most of the certain metals accumulate mainly in the liver, kidney, and gills. Fish muscles matched to the other tissues; usually carry the deepest levels of metals. , The collection of heavy metals in several organs of fish may cause skeletal lesions and operative disturbances [68].

\subsubsection{Effect on growth rates \& development.}

Heavy Metals are known for hitting every part or organ of fishes. Some of these particular elements, like Lead, Arsenic, Cadmium, and Chromium, show disadvantageous impacts on aquaculture. Lead originates from both anthropogenic as well as natural sources. The expression of $\mathrm{Pb}$ can cause many influences, depending on the concentrations and duration of $\mathrm{Pb}$ exposure. The maturity of a fish from fry is restrained by huge concentrations of $\mathrm{Pb}[69]$. Cadmium and lead bind to calmodulin, a sensor protein of free calcium influencing several cellular functions. Cadmium is recognized to degrade the activity of various catalysts of oxidative metabolism: citrate synthase, succinate dehydrogenase (SDH), glucose-6-phosphate dehydrogenase (G6PDH), and lactate dehydrogenase [70-73].

\subsubsection{Effect on the reproductive system.}

Various studies on fishes like Noemacheilus barbatulus, Perca fluviatilis, Catostomus commersoni, Oreochromis mossambicus, and Oreochromis aureus revealed that higher concentrations of zinc, lead, cadmium, copper, mercury, and cadmium were observed in the gonads of fishes. This led to the contamination of eggs and sperm and skeptically affected fish fertility and embryonic maturation [74-78]. Methylmercury caused a notable diminution in the motility of sperms. Heavy metals have disrupted the morphology of embryos as well as the metabolic process of fishes [79]. Anatomical and functional disturbances during embryonic development resulted in a reduced number of hatched larvae. Several newly hatched larvae died just after hatching due to lead and copper absorptions [80]. Hg altered embryos show 
cardiovascular troubles (heart underdevelopment - ventricle deficiencies and abnormal heart distribution; in extreme cases, the heart was a defectively beating tube inefficient to pump blood, and sometimes the heart was missing-no cardiac muscle tissue was recognized; the embryos also pointed blood clots and hemorrhages); (2) skeletal abnormalities; (3) cranial distortions [81]. Heavy metal sensitivity corrupts estrogenic and androgenic secretion and produces pathological differentiation in fish [82]. The varied pollutants such as industrial and agriculture waste, pesticides, and heavy metals have histopathological outcomes on the reproductive tissues of fish gonads $[83,84]$. These issues may disrupt the maturity of the germ cell and may diminish the capacity of the fish to breed [85].

\subsubsection{Effect on Gills and respiratory damage.}

Heavy metals enter fish bodies in three potential ways: by gills, by the digestive tract, and by body surface. The gills are recognized as a notable site for the primary uptake of metals from the water [86, 87]. Zinc accumulates on the gills of fish. It implies a disheartening effect on tissue respiration turning to hypoxia, which terminates in death. Zinc contamination also stimulates changes in ventilator and heart anatomy [88]. Zinc is an indispensable toxicant to fish which disrupts gill tissue, causes distress of acid-base and ion regulation, and hypoxia [89, 90]. Some species of fishes have a toxic impact of chromium as repeated in the blood changes such as eosinophilia, anemia, lymphocytosis, renal and bronchial lesions. Chromium is known for its minor accumulation in fish bodies, while the higher intensities of $\mathrm{Cr}$ damage the gills of fish swimming near the point of $\mathrm{Cr}$ distribution [91].

\subsubsection{Neurotoxic effect.}

Important heavy metal for neurotoxicity is mercury. While others contribute to neurotoxicity, $\mathrm{Hg}$ is significant in affecting fishes as well as humans. Monomethyl $\mathrm{Hg}$ provokes damage to the brain, while fetal and postnatal expressions have given rise to an abortion, congenital deformity, and development differences in young fry. $\mathrm{Hg}$ poisoning of waterways in Japan. The $\mathrm{Hg}$ toxicity (by methyl $\mathrm{Hg}$ ) and Minamata disease exhibited significant neurotoxicity [92].

\subsubsection{Effect on blood \& circulatory system.}

Nickel is required in small quantities to assemble red blood cells (RBCs), but it becomes imperceptibly toxic in abundant quantities. Cadmium is associated with causing an accession in blood pressure and myocardial disease in fishes [92]. According to research, mercury induces harm to the blood vessels, hemorrhages, and depletion of the blood cell count of a fish. chromium influences the blood following anemia, eosinophilia, and lymphocytosis, bronchial, and renal injuries [81,91].

\subsubsection{Genotoxic effect.}

Arsenic behaves to coagulate protein; it makes associations with coenzymes and restrains the generation of adenosine triphosphate (ATP) throughout respiration [93]. It is perhaps cancer-causing in aggregates of all its oxidation states, and high-level expression can cause death $[94,95]$. Notwithstanding the carcinogenic outcomes of heavy metals that are not known well, several studies suggest genotoxic effects may exist [96]. Arsenic composites 
restrain DNA repair and provoke chromosomal derangements, sister-chromatid transfers, and micronuclei development in cells [97]. Carcinogenic metals, including cadmium, arsenic, nickel, and chromium, have correlated with DNA destruction by base-pair deletion, mutation, or radical oxygen attack on DNA [98].

\subsubsection{Physiological damage.}

Several histological modifications like gill mortification or fatty degeneration of the liver happen at intervals in the fish and crustaceans [99, 100]. Cadmium, nickel, mercury, chromium, lead, and arsenic are accountable for malformations in fishes. Multiple physiological changes are observed when these heavy metals are present in plentiful amounts. Shortening of fins, underdevelopment of gills, liver, and fin functions of fingerlings were common pronouncements in the analyses [101]. In extension to the reproduction, hypoxic situations, unnecessary stocking and starvation, heavy metals like lead, arsenic, cadmium, and zinc also induced stress in fish $[102,103]$. Stress agents, including pollution, affected growth, development, and reproduction, are unsympathetically by alternating metabolic, physiological, and biochemical processes [104, 105].

\subsubsection{Effect on lifespan \& mortality.}

Studies carried out on fish revealed that all heavy metals, even though some of them are essential for life, have adverse effects on living organisms through metabolic interference and mutagenesis. These adverse effects are a decrease in fitness, interference in reproduction that leads to carcinoma, and eventually death [89]. Mortality, reproduction, individual growth rates, and physiological capacities in fish are most influenced by the toxic consequences of heavy metals. Inopportune impacts on physiological functions and biochemical parameters both in blood and tissue of the fish living in metal-polluted waters have been discerned. It has been informed that fish imperiled to metals showed immune system faults and thus became vulnerable to infectious diseases and had a more prominent mortality chance [106-113].

\section{Intake of heavy metal through food chain}

These heavy metals enter our bodies via diet, water, and air to a smaller extent. Some of these heavy metals, like zinc, copper, and selenium, are crucial for maintaining the metabolism. But at greater intensities, they can lead to poisoning. Heavy metal poisoning could emerge from contaminated-drinking water (lead pipes), great ambient air concentrations near emanation sources, or intake through the food chain. Heavy metals direct to bioaccumulate in the body and so are vulnerable to humans. Bioaccumulation signifies an accretion in the absorption of a chemical in an organism, matched to a chemical's concentration in the atmosphere [114].

Indeed, the accumulation of metals in food crops and their effects on human wellness is of prominent interest globally. However, information on geophysical trends may help us recognize the degree of their consequence on human health. Difficulties may vary across countries, along with the origin of metallic pollutants, which has been interpreted scantily [115]. Heavy metals are recognized as toxicants, which exhibit acute disorders in aquatic animals. Absorption of heavy metals through the food chain in aquatic organisms may produce several pathological dysfunctions like sporadic fever, cramps, renal damage, and hypertension in humans. The fish serve a significant purpose for biomagnifications of metals as they stand 
at the tip of the food pyramid and act as permissible transfer media to human beings [116, 117]. Heavy metals can be critically deleterious to individuals, having poisonous and cancerous effects and generating the oxidative degeneration of biological macromolecules.

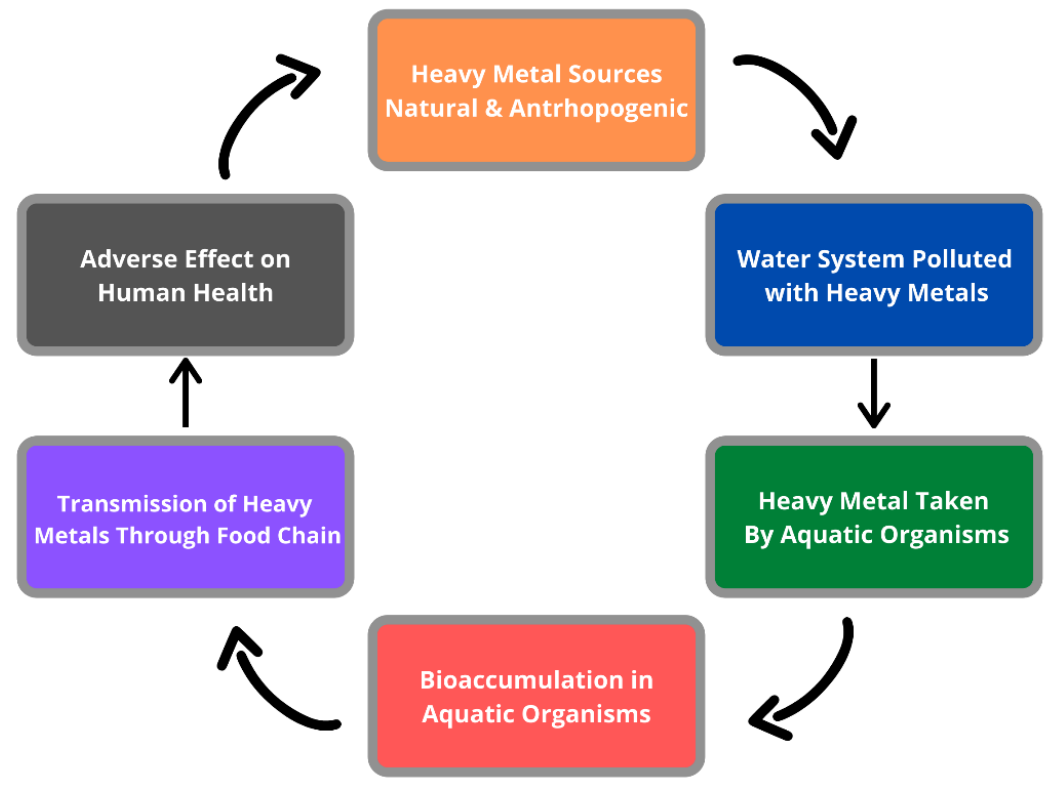

Figure 2. People intake heavy metal to the food chain.

\section{Heavy metals toxic effect on human health}

Heavy metals are actively involved in the rise of numerous diseases, including diabetes, Alzheimer's disease, and different forms of cancer [118]. Besides unique metals show specific indications of their toxicity, the following have been described as general signs associated with copper, lead, aluminum, zinc, mercury, cadmium, and arsenic, poisoning: gastrointestinal (GI) dysfunctions, diarrhea, stomatitis, shivering, hemoglobinuria inducing a rust-red depression, and pneumonia (when volatile vapors and fumes are inhaled). The character of the effects could be virulent (acute, chronic, or sub-chronic), mutagenic, teratogenic, neurotoxic, or carcinogenic [119]. Extended exposure may succeed in gradually advancing muscular dystrophy, Parkinson's disease, and multiple sclerosis. Allergies are not rare and recurred long-term association with any metals, or their compounds may even provoke carcinoma $[120,121]$.

\subsection{Lead $(P b)$.}

Lead is a hazardous metal that readily gets accumulated in the human body. It is heavy, and soft metal exists in the form of sulfide, cerussite $\left(\mathrm{PbCl}_{2}\right)$, and galena. The main purpose of the association of lead in the industrial effluent is chiefly due to Lead-acid battery wastewater. Lead usually appears in wastewaters from industries like electroplating industries, electrical industries, steel industries, explosive manufacturers, etc. [122]. Lead is frequently deposited in aquatic systems through electronic wastes. Lead is an unsafe element. Most of the industrial effluents consist of lead in more prominent quantities. Lead produces memory dysfunction, hearing quandaries, digestive difficulties in humans. Lead is carcinogenic. Changeless damage can be created to the Central Nervous System (CNS), Brain and Excretory system when lead is absorbed in higher volumes [123]. 


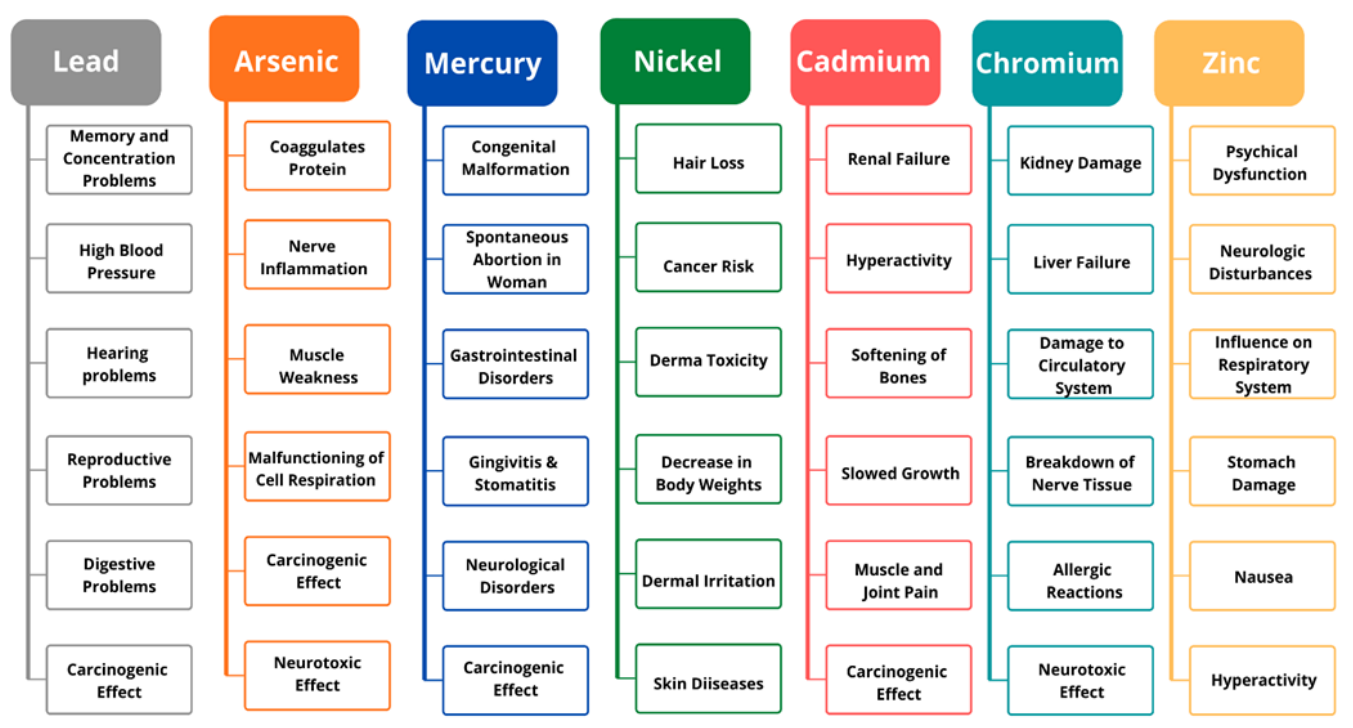

Figure 3. Heavy metal toxic effect on human health.

\subsection{Arsenic (As).}

The smelting method of lead, copper, and zinc is responsible for discharging arsenic into the environment. In addition to it, the composition of chemicals and glasses is also accountable to produce arsenic. The production of pesticides that comprise arsenic releases arsine gas $[124,125]$. Arsenic has many sources, like industrial wastes, metallic wastes, etc. Arsenic is pretty dangerous to human wellness as it negatively influences the nervous system; it undermines muscles and coagulates protein. It can commence cancer. It also influences the endocrine system, hepatic system, and reproductive system [126, 127].

\section{3. $\operatorname{Mercury}(\mathrm{Hg})$.}

Mercury displays the impact of neurotoxicity when flashed in greater quantity, CNS is the major target for the element's vapours. Involuntary Abortion in pregnant ladies is common when mercury is absorbed in greater concentrations. Broad diversity of cognitive, personality, sensory, and motor disorders have been proclaimed. Some long-term exposures to elemental mercury vapor have resulted in unsteady walking, poor concentration, tremulous speech, blurred vision, performance decreases in psychomotor skills. Chronic cough has been reported in subjects exposed to elemental mercury vapor for several weeks [128]. Numerous earlier researchers recommend that inorganic mercury may be embryotoxic and even teratogenic. Cardiovascular effects and gastrointestinal outcomes have also been seen when mercury is devoured [129].

\subsection{Cadmium $(C d)$.}

Cadmium appears in the form of natural sediments, which consist of other elements. It is also the most toxic heavy metal found in manufacturing effluents. It plays a major role in industries like plating, cadmium - nickel battery, phosphate fertilizers, stabilizers, and alloys. Even at low intensities, the cadmium compounds are hugely destructive and get accumulated in the ecosystem. Cadmium accumulation may result in "Itai-Itai" disease. It causes the tempering of the bones and fractures to human beings [130]. Cadmium manifests renal toxicity when taken in higher amounts. Cadmium was blazoned to cause kidney defect and softening of bones following long-term or high dose exposure [131], and elevated levels of Cd have been 
proclaimed to cause prostate cancer [132]. Cadmium is accountable for the huge risk of lung cancer [133].

\subsection{Nickel (Ni).}

Natural sources of atmospheric nickel include specks of dust from volcanic emissions and the weathering of rocks and soils. Appearances by inhalation, ingestion, or skin association occur in nickel and nickel alloy production plants as well as in welding, electroplating, grinding, and cutting operations. Nickel causes a variety of pathologic effects and is known for the carcinogenic effect on humans. Skin contact with metallic or soluble nickel compounds can produce allergic dermatitis. A significant shrinkage in body weight is seen in Nickel consumption [134]. The prominent effect of nickel overdose is Hair Loss. The most serious harmful health effects from exposure to nickel, such as chronic bronchitis, reduced lung function, and cancer of the lung and nasal sinus, have happened in people who have inhaled dust containing certain nickel compounds [135-138].

\subsection{Chromium $(\mathrm{Cr})$.}

Because of anthropogenic actions, natural water is being spoiled by this metal. Some of the species of fishes have a destructive effect on chromium [91]. Various examinations have explained that chromium composites can advance the danger of lung cancer [139-141]. Damage to the Circulatory and collapse of nerve tissue can also be witnessed in the system. The residence of $\mathrm{Cr}$ with other metals was reported to enhance the glycogen level in several organs displaying the stress due to the metal exposure [142].

\subsection{Zinc.}

The sources of zinc waters may be from human activities or from geological rock weathering such as industrial and domestic wastewater outflows and animals, where it creates essential roles in maintaining cytoplasmic integrity. Zinc is considered vital for immune responses. Zinc adds to increasing the risk of cardiovascular diseases. It can cause hypertension, Nausea, and Stomach Damage. It is also liable for Neurotoxic outcomes on human health. Zinc can cause psychical dysfunctions when employed in abundance. Several neural changes are also generated due to the introduction of zinc in the body [67, 143, 144].

\section{Discussion}

Heavy metals are essential vital elements needed for the proper growth and development of a human body. An increase in the human population has caused an increment in industrial waste, medical waste, and pollution. This waste and discharge from various sources have resulted in water pollution, causing harm to aquaculture. Directly or indirectly, all waste containing harmful heavy metals is deposited in water bodies. It results in an adverse effect on the growth and development of aquatic organisms. The use of fertilizers, industrial effluents, and medical waste is directly associated with groundwater tables that are connected to nearby freshwater sources. Heavy metals in excess amounts may result in breeding complications, physical deformities, and even threatening survival capacities. Fishes are one of the cheapest and easy sources for fatty acids, lipids, and proteins. Fish accounts for nearly $20 \%$ of total animal consumption in the world. Fish consumption is an essential part of the diet for the people living in the areas of seashores and water bodies. Consumption of fish enriched 
in heavy metals may affect not only human health but also disturbs the whole food chain. Humans may develop grave issues regarding organ failures, physical disfigurement, and even disturbs mental health.

\section{Conclusion}

The presence of excess amounts of heavy metals in water figures or aquaculture is an issue of major concern. Removal of heavy metals from wastewaters is needed to prioritize. Wastewater must be treated so that contaminants, pollutants, and undesirable components shall be reduced prior to discharge into freshwater or water sources. Heavy metal detection methods must be used in industries before discharging the waste into water bodies. Various chemical methods and instruments must be used to find out the concentrations of heavy metals in wastewaters. Guidance must be given to these industries recommended by the norms of WHO. Medical waste should be strictly dumped into specific locations that are not connected to drainage systems or groundwater tables so that they will not enter the source of water bodies. Water treatment plants must be set up and used wisely prior to discharge of any effluents in water bodies. Awareness must be spread among industrial workers, medical cleaning staff, cleaners, and sweepers, etc. These people will be helpful in reducing waste from various sources. Special awareness programs must be created for farmers to showcase the harmful effects of excessive usage of agrochemicals in farming. Guidance should be given to the people living on the banks of seashore or rivers to test the fishes for the presence of heavy metals prior to consumption. Regular testing of the water sources shall be carried out by responsible authorities with newer and advanced techniques. Academic education must involve methodologies to aware future generations about heavy metals and their toxic effect on the environment.

\section{Funding}

This research received no external funding.

\section{Acknowledgments}

This research has no acknowledgment.

\section{Conflicts of Interest}

The authors declare no conflict of interest.

\section{References}

1. Treatment, L. Water Treatment, Published by Lenntech Water Treatment and Air Purification Rotterdamseweg. Netherlands. 2004.

2. Singh Sankhla, M.; Kumar, R.; Prasad, L. Variation of Chromium Concentration in Yamuna River (Delhi) Water due to Change in Temperature and Humidity. Seybold Report 2020, 15, 293-299.

3. Yilmaz, A.B. Levels of heavy metals ( $\mathrm{Fe}, \mathrm{Cu}, \mathrm{Ni}, \mathrm{Cr}, \mathrm{Pb}$, and $\mathrm{Zn}$ ) in tissue of Mugil cephalus and Trachurus mediterraneus from Iskenderun Bay, Turkey. Environmental Research 2003, 92, 277-281, https://doi.org/10.1016/S0013-9351(02)00082-8.

4. Marcovecchio, J.E. The use of Micropogonias furnieri and Mugil liza as bioindicators of heavy metals pollution in La Plata river estuary, Argentina. Science of The Total Environment 2004, 323, 219-226, https://doi.org/10.1016/j.scitotenv.2003.09.029

5. Joseph, B.; Raj, J.S.; Edwin, B.; P, D.S.; Jeevitha, M.V.; Ajisha, S.U.; S Rajan, S. Toxic effect of heavy metals on aquatic environment. International Journal of Biological and Chemical Sciences 2011, 4, https://doi.org/10.4314/ijbcs.v4i4.62976. 
6. He, Z.L.; Yang, X.E.; Stoffella, P.J. Trace elements in agroecosystems and impacts on the environment. Journal of Trace Elements in Medicine and Biology 2005, 19, 125-140, https://doi.org/10.1016/j.jtemb.2005.02.010.

7. Olaifa, F.E.; Olaifa, A.K.; Onwude, T.E. Lethal and sub-lethal effects of copper to the African catfish (Clarias gariepinus) juveniles. African Journal of Biomedical Research 2004, 7, https://doi.org/10.4314/ajbr.v7i2.54071.

8. Yadav, H.; Kumar, R.; Sankhla, M.S. Residues of Pesticides and Heavy Metals in Crops Resulting in Toxic Effects on Living Organism. Journal of Seybold Report 2020, 15, 1527-1541.

9. Gadd, G.M.; Griffiths, A.J. Microorganisms and heavy metal toxicity. Microbial Ecology 1977, 4, 303-317, https://doi.org/10.1007/BF02013274.

10. Sankhla, M. S.; Kumar, R.; Shefali. New and Advanced Technologies in Aquaculture to Support Environmentally Sustainable Development. Microbial Biotechnology: Basic Research and Applications, Springer 2020, 1, 249-263, https://doi.org/10.1007/978-981-15-2817-0_11.

11. Farkas, A.; Salanki, J.; Specziar, A. Relation between growth and the heavy metal concentration in organs of bream Abramis brama L. populating Lake Balaton. Archives of environmental contamination and toxicology, 2002, 43, 236-243, https://doi.org/10.1007/s00244-002-1123-5.

12. Baatrup, E. Structural and functional effects of heavy metals on the nervous system, including sense organs, of fish. Comparative Biochemistry and Physiology Part C: Comparative Pharmacology 1991, 100, 253-257, https://doi.org/10.1016/0742-8413(91)90163-N.

13. Singh Sankhla, M.; Kumari, M.; Nandan, M.; Kumar, R.; Agrawal, P. Heavy Metals Contamination in Water and their Hazardous Effect on Human Health-A Review. International Journal of Current Microbiology and Applied Sciences 2016, 5, 759-766, https://dx.doi.org/10.2139/ssrn.3428216.

14. Kabata-Pendias, A.; Pendias, H. Trace elements in soil and plants. No. 631.41, 1984.

15. Herawati, N.; Suzuki, S.; Hayashi, K.; Rivai, I.F.; Koyama, H. Cadmium, Copper, and Zinc Levels in Rice and Soil of Japan, Indonesia, and China by Soil Type. Bulletin of Environmental Contamination and Toxicology 2000, 64, 33-39, https://doi.org/10.1007/s001289910006.

16. Hazards, V. A Sourcebook on the Effects of Eruptions. 1984.

17. Stewart, C.; Johnston, D.M.; Leonard, G.S.; Horwell, C.J.; Thordarson, T.; Cronin, S J. Contamination of water supplies by volcanic ashfall: a literature review and simple impact modelling. Journal of Volcanology and Geothermal Research 2006, 158, 296-306, https://doi.org/10.1016/j.jvolgeores.2006.07.002.

18. Nagajyoti, P.C.; Lee, K.D.; Sreekanth, T.V.M. Heavy metals, occurrence and toxicity for plants: a review. Environmental Chemistry Letters 2010, 8, 199-216, https://doi.org/10.1007/s10311-010-0297-8

19. Ali, H.; Khan, E.; Ilahi, I. Environmental Chemistry and Ecotoxicology of Hazardous Heavy Metals: Environmental Persistence, Toxicity, and Bioaccumulation. Journal of Chemistry 2019, 2019, https://doi.org/10.1155/2019/67303051.

20. Lobinski, R., Moulin, C., \& Ortega, R. Imaging and speciation of trace elements in biological environment. Biochimie, 2006, 88(11), 1591-1604., https://doi.org/10.1016/j.biochi.2006.10.003

21. Afzal, M.S.; Ashraf, A.; Nabeel, M. Characterization of industrial effluents and groundwater of Hattar industrial estate, Haripur. Advances in Agriculture and Environmental Science: Open Access 2018, 1, 7077, https://doi.org/10.30881/aaeoa.00013.

22. Edokpayi, J.; Odiyo, J.; Durowoju, O. Impact of Wastewater on Surface Water Quality in Developing Countries: A Case Study of South Africa. Water quality 2017, 401-416, https://doi.org/10.5772/66561.

23. Mateo-Sagasta, J.; Zadeh, S. M.; Turral, H.; Burke, J. Water pollution from agriculture: a global review. Executive summary. Rome, Italy: FAO Colombo, Sri Lanka: International Water Management Institute (IWMI). CGIAR Research Program on Water, Land and Ecosystems (WLE). 2017.

24. Verma, N.; Kumar, R.; Singh Sankhla, M.; Parihar, K. Green Filter Development: An Innovative Technique for Removal of Heavy Metals from Water. ARC Journal of Forensic Science 2020, 5, 7-12, http://dx.doi.org/10.20431/2456-0049.0501002.

25. Schreinemachers, P.; Tipraqsa, P. Agricultural pesticides and land use intensification in high, middle and low income countries. Food Policy 2012, 37, 616-626, https://doi.org/10.1016/j.foodpol.2012.06.003.

26. Peplow, D. Environmental impacts of mining in Eastern Washington. University of Washington Water Center 1999.

27. Sumi, L.; Thomsen, S. Mining in remote areas: Issues and impacts. Environmental Mining Council of British Columbia. MiningWatch Canada/Mines Alerte, Ottawa, Ontario 2001.

28. Jhariya, D.; Khan, R.; Thakur, G. S. Impact of mining activity on water resource: an overview study. Proceedings of the Recent Practices and Innovations in Mining Industry, Raipur, India 2016, 19-20.

29. Anju. K.R.; Binu Kumari. S; Mohan Kumar, M.; Sujila, T.; Drishya, M.K.; Sruthi, G. A Study On The Effect Of Electroplating Effluent On The Haematological And Genotoxicological Analysis Of The Freshwater Fish, Oreochromis Mossambicus. International Journal Of Pharmacy And Biological Sciences 2018, 8, 969-975.

30. Prakash, S.; Manhart, A.; Amoyaw-Osei, Y.; Agyekum, O. O. Socio-economic assessment and feasibility study on sustainable e-waste management in Ghana. Öko-Institut eV in cooperation with Ghana Environmental Protection Agency (EPA) \& Green Advocacy Ghana, Ministry of Housing, Spatial Planning and the Environment, VROM-Inspectorate $\mathbf{2 0 1 0 .}$ 
31. Azuka, A.I. The influx of used electronics into Africa: a perilous trend. Law Env't \& Dev. J. 2009, 5.

32. Singh, G. P.; Chaturvedi, B.; Kumar, R. Effect of Electronic waste on Environmental \& Human health-A Review. IOSR Journal of Environmental Science, Toxicology and Food Technology (IOSR-JESTFT) 2016, 10, 2319-2399, https://doi.org/10.9790/2402-10090198104.

33. Parihar, K.; Sankhla, M.S.; Kumar, R. Water Quality Status of Yamuna River and its Toxic Effects on Humans. Environ Anal Eco stud. 2019, 6, 597-601, https://doi.org/10.31031/EAES.2019.06.000628.

34. Manzoor, J.; Sharma, M. Impact of Biomedical Waste on Environment and Human Health. Environmental Claims Journal 2019, 31, 311-334, https://doi.org/10.1080/10406026.2019.1619265

35. Clark, B. Thermal Water Pollution from Nuclear Power Plants. 2019.

36. Osann, E.; Hayat, B. Protecting Our Waters from Toxic Power Plant Discharges and Reducing Water Use in the Process. NRDC Fact Sheet 2014.

37. Feeley, T.I.I.I.L.G.; McNemar, A.; Carney, B. A.; Pletcher, S. Department of Energy/Office of Fossil Energy's Water-Energy Interface Research Program. DOE/FE's power plant water management R\&D program summary 2006, 6-7.

38. Prince Prakash Jebakumar, J.; Nandhagopal, G.; Rajan Babu, B.; Ragumaran, S.; Ravichandran, V. Impact of coastal power plant cooling system on planktonic diversity of a polluted creek system. Marine Pollution Bulletin 2018, 133, 378-391, https://doi.org/10.1016/j.marpolbul.2018.05.053.

39. Eaton, J.G.; Scheller, R.M. Effects of climate warming on fish thermal habitat in streams of the United States. Limnology and Oceanography 1996, 41, 1109-1115, https://doi.org/10.4319/lo.1996.41.5.1109.

40. Moberg, F.; Folke, C. Ecological goods and services of coral reef ecosystems. Ecological Economics 1999, 29, 215-233, https://doi.org/10.1016/S0921-8009(99)00009-9.

41. Frémion, F.; Bordas, F.; Mourier, B.; Lenain, J.-F.; Kestens, T.; Courtin-Nomade, A. Influence of dams on sediment continuity: A study case of a natural metallic contamination. Science of The Total Environment 2016, 547, 282-294, https://doi.org/10.1016/j.scitotenv.2016.01.023.

42. Hasan, M.R.; Khan, M.Z.H.; Khan, M.; Aktar, S.; Rahman, M.; Hossain, F.; Hasan, A.S.M.M. Heavy metals distribution and contamination in surface water of the Bay of Bengal coast. Cogent Environmental Science 2016, 2, https://doi.org/10.1080/23311843.2016.1140001.

43. Varol, M.; Şen, B. Assessment of nutrient and heavy metal contamination in surface water and sediments of the upper Tigris River, Turkey. Catena 2012, 92, 1-10, https://doi.org/10.1016/j.catena.2011.11.011.

44. Equeenuddin, S.M.; Tripathy, S.; Sahoo, P.K.; Panigrahi, M.K. Metal behavior in sediment associated with acid mine drainage stream: Role of pH. Journal of Geochemical Exploration 2013, 124, 230-237, https://doi.org/10.1016/j.gexplo.2012.10.010.

45. Vasile, G.; Cruceru, L.; Petre, J.; Iancu, V.-I. Complex analytical investigations regarding the bio-availability of heavy metals from sediments. Revista de Chimie -Bucharest- Original Edition- 2005, 56, 790-794.

46. Griscom, S.B.; Fisher, N.S. Bioavailability of sediment-bound metals to marine bivalve molluscs: An overview. Estuaries 2004, 27, 826-838, https://doi.org/10.1007/BF02912044

47. Roosa, S.; Prygiel, E.; Lesven, L.; Wattiez, R.; Gillan, D.; Ferrari, B.J.D.; Criquet, J.; Billon, G. On the bioavailability of trace metals in surface sediments: a combined geochemical and biological approach. Environmental Science and Pollution Research 2016, 23, 10679-10692, https://doi.org/10.1007/BF02912044.

48. Fu, J.; Zhao, C.; Luo, Y.; Liu, C.; Kyzas, G.Z.; Luo, Y.; Zhao, D.; An, S.; Zhu, H. Heavy metals in surface sediments of the Jialu River, China: Their relations to environmental factors. Journal of Hazardous Materials 2014, 270, 102-109, https://doi.org/10.1016/j.jhazmat.2014.01.044.

49. Bonnail, E.; Sarmiento, A.M.; DelValls, T.A.; Nieto, J.M.; Riba, I. Assessment of metal contamination, bioavailability, toxicity and bioaccumulation in extreme metallic environments (Iberian Pyrite Belt) using Corbicula fluminea. Science of The Total Environment 2016, 544, 1031-1044, https://doi.org/10.1016/j.scitotenv.2015.11.131.

50. Bryan, G.W.; Langston, W.J.; Hummerstone, L.G.; Burt, G.R. A guide to the assessment of heavy metal contamination in estuaries using biological indicators. Occasional Publication of the Marine Biological Association 1985, 4.

51. Roesijadi, G. Metal regulation in aquatic animals: Mechanism of uptake, accumulation and release. Molecular mechanisms in aquatic toxicology 1994, 387-420.

52. Wojtkowska, M.; Bogacki, J.; Witeska, A. Assessment of the hazard posed by metal forms in water and sediments. Science of The Total Environment 2016, 551-552, 387-392, https://doi.org/10.1016/j.scitotenv.2016.01.073.

53. Wang, W.X.; Fisher, N.S. Modeling metal bioavailability for marine mussels. In: Reviews of environmental contamination and toxicology. Springer, New York, NY. 1997; pp. 39-65, https://doi.org/10.1007/978-14612-1958-3_2.

54. Chapman, P.M.; Wang, F.; Janssen, C.; Persoone, G.; Allen, H.E. Ecotoxicology of metals in aquatic sediments: binding and release, bioavailability, risk assessment, and remediation. Canadian Journal of Fisheries and Aquatic Sciences 1998, 55, 2221-2243, https://doi.org/10.1139/f98-145

55. Bryan, G.W. Some aspects of heavy metal tolerance in aquatic organisms. Effects of pollutants on aquatic organisms 1976, 193. 
56. Förstner, U. Contaminated sediments: lectures on environmental aspects of particle-associated chemicals in aquatic systems. Springer. Volume 21, 2006,

57. Adams, W.J.; Chapman, P.M. Assessing the hazard of metals and inorganic metal substances in aquatic and terrestrial systems. CRC Press, 2007.

58. Rosado, D.; Usero, J.; Morillo, J. Assessment of heavy metals bioavailability and toxicity toward Vibrio fischeri in sediment of the Huelva estuary. Chemosphere 2016, 153, 10-17, https://doi.org/10.1016/j.chemosphere.2016.03.040.

59. Rahman, M.S.; Molla, A.H.; Saha, N.; Rahman, A. Study on heavy metals levels and its risk assessment in some edible fishes from Bangshi River, Savar, Dhaka, Bangladesh. Food Chemistry 2012, 134, 1847-1854, https://doi.org/10.1016/j.foodchem.2012.03.099.

60. Atici, T.; Obali, O.; Altindag, A.; Ahiska, S.; Aydin, D. The accumulation of heavy metals $(\mathrm{Cd}, \mathrm{Pb}, \mathrm{Hg}, \mathrm{Cr})$ and their state in phytoplanktonic algae and zooplanktonic organisms in Beysehir Lake and Mogan Lake, Turkey. African Journal of Biotechnology 2010, 9.

61. Srivastava, A.K.; Srivastava, A.K. Effects of chlordecone on the gonads of freshwater catfish, Heteropneustes fossilis. Bulletin of environmental contamination and toxicology 1994, 53, 186-191.7, https://doi.org/10.1007/BF00192031.

62. Roméo, M.; Siau, Y.; Sidoumou, Z.; Gnassia-Barelli, M. Heavy metal distribution in different fish species from the Mauritania coast. Science of the Total Environment 1999, 232, 169-175, https://doi.org/10.1016/S0048-9697(99)00099-6.

63. Beijer, K. Sources, transport and transformation of metals in the environment. Handbook of the Toxicology of Metals 1986, 1, 68-77.

64. Tekin-Özan, S.; Aktan, N. Relationship of heavy metals in water, sediment and tissues with total length, weight and seasons of Cyprinus carpio L., 1758 from Işikli Lake (Turkey). Pakistan Journal of Zoology, 2012, 44, 1405-1416.

65. Nagaratnamma, R.; Ramamurthi, R. Metabolic depression in the freshwater teleost, Cyprinus carpio exposed to an organophosphate pesticide. Current Science (India) 1982, 72.

66. Cairns, V.W.; Hodson, P.V.; Nriagu, J.O. Contaminant effects on fisheries. Osti Gov 1984, 73.

67. Afshan, S.; Ali, S.; Ameen, U.; Farid, M.; Bharwana, S.; Hannan, F.; Ahmad, R. Effect of Different Heavy Metal Pollution on Fish. Research Journal of Chemical and Environmental Sciences 2014, 2, 74-79.

68. Jezierska, B.; Witeska, M. The metal uptake and accumulation in fish living in polluted waters. In: Soil and water pollution monitoring, protection and remediation. Springer, Dordrecht. Volume 75, 2006; pp. 107114, https://doi.org/10.1007/978-1-4020-4728-2_6.

69. Huseen, H.M.; Mohammed, A.J. Heavy Metals Causing Toxicity in Fishes. Journal of Physics: Conference Series 2019, 1294, https://doi.org/10.1088/1742-6596/1294/6/062028.

70. Behra, R. In vitro effects of cadmium, zinc and lead on calmodulin-dependent actions inOncorhynchus mykiss, Mytilus sp., andChlamydomonas reinhardtii. Archives of Environmental Contamination and Toxicology 1993, 24, 21-27, https://doi.org/10.1007/BF01061085.

71. Couture, P.; Rajender Kumar, P. Impairment of metabolic capacities in copper and cadmium contaminated wild yellow perch (Perca flavescens). Aquatic Toxicology 2003, 64, 107-120, https://doi.org/10.1016/S0166-445X(03)00028-6.

72. Hilmy, A.M.; Shabana, M.B.; Daabees, A.Y. Bioaccumulation of cadmium: Toxicity in Mugil cephalus. Comparative Biochemistry and Physiology Part C: Comparative Pharmacology 1985, 81, 139-144, https://doi.org/10.1016/0742-8413(85)90105-7.

73. Osman, A.G.M.; Mekkawy, I.A.; Verreth, J.; Kirschbaum, F. Effects of lead nitrate on the activity of metabolic enzymes during early developmental stages of the African catfish, Clarias gariepinus (Burchell, 1822). Fish Physiology and Biochemistry 2007, 33, 1-13, https://doi.org/10.1007/s10695-006-9111-8.

74. Szarek-Gwiazda, E. Heavy metal contents in stone loach Noemacheilus barbatulus(L.)(Cobitidae) living in the river above and below dam reservoir(Dobczyce Reservoir, southern Poland). Polish Journal of Ecology 1999, 47, 145-152.

75. Ellenberger, S.A.; Baumann, P.C.; May, T.W. Evaluation of Effects Caused by High Copper Concentrations in Torch Lake, Michigan, on Reproduction of Yellow Perch. Journal of Great Lakes Research 1994, 20, 531-536, https://doi.org/10.1016/S0380-1330(94)71169-2.

76. Miller, P.A.; Munkittrick, K.R.; Dixon, D.G. Relationship between Concentrations of Copper and Zinc in Water, Sediment, Benthic Invertebrates, and Tissues of White Sucker (Catostomus commersoni) at MetalContaminated Sites. Canadian Journal of Fisheries and Aquatic Sciences 1992, 49, 978-984, https://doi.org/10.1139/f92-109.

77. Pelgrom, S.M.G.J.; Lamers, L.P.M.; Lock, R.A.C.; Balm, P.H.M.; Bonga, S.E.W. Interactions between copper and cadmium modify metal organ distribution in mature tilapia, Oreochromis mossambicus. Environmental Pollution 1995, 90, 415-423, https://doi.org/10.1016/0269-7491(95)00022-J.

78. Allen, P. Accumulation profiles of lead and cadmium in the edible tissues of Oreochromis aureus during acute exposure. Journal of Fish Biology 1995, 47, 559-568, https://doi.org/10.1111/j.10958649.1995.tb01922.x. 
79. Perry, D.M.; Weis, J.S.; Weis, P. Cytogenetic effects of methylmercury in embryos of the killifish,Fundulus heteroclitus. Archives of Environmental Contamination and Toxicology 1988, 17, 569-574, https://doi.org/10.1007/BF01055824.

80. Jezierska, B.; Ługowska, K.; Witeska, M. The effects of heavy metals on embryonic development of fish (a review). Fish Physiology and Biochemistry 2009, 35, 625-640, https://doi.org/10.1007/s10695-008-9284-4.

81. Weis, J.S.; Weis, P.; Heber, M.; Vaidya, S. Methylmercury tolerance of killifish (Fundulus heteroclitus) embryos from a polluted vs non-polluted environment. Marine Biology 1981, 65, 283-287, https://doi.org/10.1007/BF00397123.

82. Ebrahimi, M.; Taherianfard, M. The effects of heavy metals exposure on reproductive systems of cyprinid fish from Kor River. Iranian Journal of Fisheries Sciences 2011, 10, 13-26.

83. Johnson, L.L.; Casillas, E.; Myers, M.S.; Rhodes, L.D.; Paul Olson, O. Patterns of oocyte development and related changes in plasma 17- $\beta$ estradiol, vitellogenin, and plasma chemistry in English sole Parophrys vetulus Girard. Journal of Experimental Marine Biology and Ecology 1991, 152, 161-185, https://doi.org/10.1016/0022-0981(91)90213-G.

84. Lye, C.; Frid, C.; Gill, M.E. Seasonal reproductive health of flounder Platicthys flesus exposed to sewage effluent. Marine Ecology-progress Series 1998, 170, 249-260, https://doi.org/10.3354/meps170249.

85. Inbamani, N.; Seenivasan, R. Effect of phosphamidon toxicity and pesticidal histopathology on the fish Sarotherodon mossambica. Journal of Ecotoxicology \& Environmental Monitoring 1998, 8, 85-95.

86. Roméo, M.; Siau, Y.; Sidoumou, Z.n.; Gnassia-Barelli, M. Heavy metal distribution in different fish species from the Mauritania coast. Science of The Total Environment 1999, 232, 169-175, https://doi.org/10.1016/S0048-9697(99)00099-6.

87. Beijer, K. Sources, transport and transformation of metals in the environment. Handbook of the Toxicology of Metals 1986, 1 .

88. Olaifa, F.E.; Olaifa, A.K.; Onwude, T.E. Lethal and sub-lethal effects of copper to the African catfish (Clarias gariepinus) juveniles. African Journal of Biomedical Research 2004, 7, https://doi.org/10.4314/ajbr.v7i2.54071.

89. Vosylienè, M.Z.; Mikalajūnè, A. Effect of heavy metal model mixture on rainbow trout biological parameters. Ekologija 2006, 4, 12-17.

90. Murugan, S.S.; Karuppasamy, R.; Poongodi, K.; Puvaneswari, S. Bioaccumulation pattern of zinc in freshwater fish Channa punctatus (Bloch.) after chronic exposure. Turkish Journal of Fisheries and Aquatic Sciences 2008, 8, 55-59.

91. Chemical properties of chromium - Health effects of chromium - Environmental effects of chromium. Website-https://www.lenntech.com/periodic/elements/cr.htm [Accessed Date - 31/7/2020]

92. Pandey, G.; Madhuri, S. Heavy metals causing toxicity in animals and fishes. Research Journal of Animal, Veterinary and Fishery Sciences 2014, 2, 17-23.

93. Sankhla, M.S.; Kumar, R. Contaminant of Heavy Metals in Groundwater \& its Toxic Effects on Human Health \& Environment. Int. J. Environ Sci Nat Res. 2019, 18, https://doi.org/10.19080/IJESNR.2019.18.555996.

94. Singh Sankhla, M.; Kumar, R.; biswas, A. Dynamic Nature of Heavy Metal Toxicity in Water and Sediments of Ayad River with Climatic Change. Int. J. Hydro 2019, 3, 339-343, https://doi.org/10.15406/ijh.2019.03.00197.

95. Ogwuegbu, M.O.; Ijioma, M.A. Effects of certain heavy metals on the population due to mineral exploitation. In: International conference on scientific and environmental Issues In the population, environment and sustainable development in Nigeria, University of Ado Ekiti, Ekiti State, Nigerian 2003; pp. 8-10.

96. Snow, E.T. Metal carcinogenesis: Mechanistic implications. Pharmacology \& Therapeutics 1992, 53, 3165, https://doi.org/10.1016/0163-7258(92)90043-Y

97. Li, J.H.; Rossman, T.G. Inhibition of DNA ligase activity by arsenite: a possible mechanism of its comutagenesis. Molecular toxicology 1989, 2, 1-9.

98. Landolph, J.R. Molecular mechanisms of transformation of C3H/10T1/2 C1 8 mouse embryo cells and diploid human fibroblasts by carcinogenic metal compounds. Environmental Health Perspectives 1994, 102, 119-125, https://doi.org/10.1289/ehp.94102s3119.

99. Sevcikova, M.; Modrá, H.; Blahová, J.; Dobsikova, R.; Plhalova, L.; Zitka, O.; Hynek, D.; Kizek, R.; Skoric, M.; Svobodova, Z. Biochemical, haematological and oxidative stress responses of common carp (Cyprinus carpio L.) after sub-chronic exposure to copper. Veterinární Medicína 2016, 61, 35-50, https://doi.org/10.17221/8681-VETMED.

100. Mishra, A.K.; Mohanty, B. Acute toxicity impacts of hexavalent chromium on behavior and histopathology of gill, kidney and liver of the freshwater fish, Channa punctatus (Bloch). Environmental Toxicology and Pharmacology 2008, 26, 136-141, https://doi.org/10.1016/j.etap.2008.02.010.

101. Nwabunike, M.O. The effects of bioaccumulation of heavy metals on fish fin over two years. Journal of Fisheries \& Livestock Production 2016, 1-7.

102. Levesque, H.M.; Moon, T.W.; Campbell, P.G.C.; Hontela, A. Seasonal variation in carbohydrate and lipid metabolism of yellow perch (Perca flavescens) chronically exposed to metals in the field. Aquatic Toxicology 2002, 60, 257-267, https://doi.org/10.1016/S0166-445X(02)00012-7. 
103. Arslan, M.; Karaytuğ, S.; Cicik, B.; Su, M.; Fakültesi, Ü.; Kampüsü, Y.; Blok, C. Bakırın Clarias lazera (Valenciennes, 1840)'da Doku Glikojen ve Serum Glukoz Düzeyi Üzerine Etkileri. Journal of Fisheries \& Aquatic Sciences 2006, 23, 23-27.

104. Heath, A.G. Uptake. Accumulation, biotransformation, and excretion of xenobiotics. Water pollution and fish physiology. CRC Press 1995, 83, 93-138, https://doi.org/10.1201/9780203718896-5.

105. Soydemir Çiftçi, N.; Korkmaz, C.; Ay, Ö.; Karayakar, F.; Cicik, B. Bakır ve Kurşunun Oreochromis niloticus'da Hepatosomatik İndeks, Gonadosomatik İndeks ve Kondüsyon Faktörü Üzerine Etkileri. Süleyman Demirel Üniversitesi Eğirdir Su Ürünleri Fakültesi Dergisi 2017, 13, 12-18, https://doi.org/10.22392/egirdir.312089.

106. Amundsen, P.-A.; Staldvik, F.J.; Lukin, A.A.; Kashulin, N.A.; Popova, O.A.; Reshetnikov, Y.S. Heavy metal contamination in freshwater fish from the border region between Norway and Russia. Science of The Total Environment 1997, 201, 211-224, https://doi.org/10.1016/S0048-9697(97)84058-2

107. Larsson, Å.; Haux, C.; Sjöbeck, M.-L. Fish physiology and metal pollution: Results and experiences from laboratory and field studies. Ecotoxicology and Environmental Safety 1985, 9, 250-281, https://doi.org/10.1016/0147-6513(85)90045-4.

108. Abel, P.D.; Papoutsoglou, S.E. Lethal toxicity of cadmium toCyprinus carpio andTilapia aurea. Bulletin of Environmental Contamination and Toxicology 1986, 37, 382-386, https://doi.org/10.1007/BF01607777

109. Sehgal, R.; Saxena, A.B. Toxicity of zinc to a viviparous fish,Lebistes reticulatus (Peters). Bulletin of Environmental Contamination and Toxicology 1986, 36, 888-894, https://doi.org/10.1007/BF01623600.

110. Nemcsók, J.G.; Hughes, G.M. The effect of copper sulphate on some biochemical parameters of rainbow trout. Environmental Pollution 1988, 49, 77-85, https://doi.org/10.1016/0269-7491(88)90015-2.

111. Çelik, E. Ş. Effect of Heavy Metals on Fish's Blood Parameters. Journal of Fisheries 2006, 23, 49-55.

112. Akgün, M.; Ali, G.; Mehmet, Y. Sakarya Nehri Çeltikçe Çayı'nda Yaşayan Leuciscus cephalus L., 1758 Dokularında Ağır Metal Birikimi. Gazi University Journal of Gazi Educational Faculty (GUJGEF) 2007, 2.

113. Al-Weher, S. Levels of Heavy Metal Cd, Cu and $\mathrm{Zn}$ in Three Fish Species Collected from the Northern Jordan Valley, Jordan. JJBS Jordan Journal of Biological Sciences 2008, 1, 41-46.

114. John, H.D. "Heavy metals" a meaningless term? (IUPAC Technical Report). Pure and Applied Chemistry 2002, 74, 793-807, https://doi.org/10.1351/pac200274050793.

115. Rai, P.K.; Lee, S.S.; Zhang, M.; Tsang, Y.F.; Kim, K.-H. Heavy metals in food crops: Health risks, fate, mechanisms, and management. Environment International 2019, 125, 365-385, https://doi.org/10.1016/j.envint.2019.01.067

116. Oze, G. O.; R. N. Oze, C. I.; Ananuso, C. Ogukwe.; H. Nwanjo. Metal Pollution of Fish of Qua-Iboe River Estuary: Health Implications. Nigerian Journal of Biochemistry and Molecular Biology. 2009, 24, 1-5.

117. Sankhla, M.S.; Kumar, R.; Prasad, L. Distribution and Contamination Assessment of Potentially Harmful Element Chromium in Water. International Medico-Legal Reporter Journal. 2019. 2, 1-6.

118. ara-Marini, M.E.; Molina-García, A.; Martínez-Durazo, Á.; Páez-Osuna, F. Trace metal trophic transference and biomagnification in a semiarid coastal lagoon impacted by agriculture and shrimp aquaculture. Environmental Science and Pollution Research 2020, 27, 5323-5336, https://doi.org/10.1007/s11356-01906788-2.

119. McCluggage, D. Heavy metal poisoning. NCS Magazine, published by the bird hospital, CO, USA $1991,70$.

120. Friend, M.A.; Kohn, J.P. Fundamentals of occupational safety and health. Rowman \& Littlefield $2018,102$.

121. Sankhla, M.S.; Kumari, M.; Sharma, K.; Kushwah, R.S.; Kumar, R. Heavy metal pollution of Holy River Ganga: A review. Int. J. Res 2018, 5, 421-436.

122. Acharya, J.; Sahu, J.N.; Mohanty, C.R.; Meikap, B.C. Removal of lead(II) from wastewater by activated carbon developed from Tamarind wood by zinc chloride activation. Chemical Engineering Journal 2009, 149, 249-262, https://doi.org/10.1016/j.cej.2008.10.029.

123. Singh Sankhla, M.; Kumar, R.; Prasad, L. Zinc Impurity in Drinking Water and Its Toxic Effect on Human Health. 2019, 17, 84-87, https://doi.org/10.5958/0974-4487.2019.00015.4.

124. Roberts, J.R. Metal toxicity in children. Training Manual on Pediatric Environmental Health: Putting it into Practice. Emeryville, CA: Children's Environmental Health Network. Environmental Health Network 1999, 1.

125. Sankhla, M.S.; Kumar, R. Arsenic-Induced Neurotoxic \& Carcinogenic Effects on Humans. Open Acc J of Toxicol. 2018, 3, https://doi.org/10.19080/OAJT.2018.03.555617.

126. Singh Sankhla, M.; Kumari, M.; Sharma, K.; Kushwah, R.; Kumar, R. Water Contamination through Pesticide \& Their Toxic Effect on Human Health. International Journal for Research in Applied Science and Engineering Technology 2018, 6, https://doi.org/10.22214/ijraset.2018.1146.

127. Mohammed Abdul, K.S.; Jayasinghe, S.S.; Chandana, E.P.S.; Jayasumana, C.; De Silva, P.M.C.S. Arsenic and human health effects: A review. Environmental Toxicology and Pharmacology 2015, 40, 828-846, https://doi.org/10.1016/j.etap.2015.09.016.

128. Singh Sankhla, M.; Kumar, R.; Agrawal, P. Arsenic in Water Contamination \& Toxic Effect on Human Health: Current Scenario of India. Journal of Forensic Sciences \& Criminal Investigation 2018, 10, 1-5, https://doi.org/10.19080/JFSCI.2018.10.555781. 
129. Fisher, J.F. Elemental mercury and inorganic mercury compounds: human health aspects. World Health Organization 2003, 1.

130. Bhatnagar, A.; Sillanpää, M. Applications of chitin-and chitosan-derivatives for the detoxification of water and wastewater-A short review. Advances in colloid and Interface science 2009, 152, 26-38, https://doi.org/10.1016/j.cis.2009.09.003.

131. Vannoort, R.W.; Thomson, B.M. 2003/04 New Zealand total diet survey: agricultural compound residue, selected contaminants and nutrients. Wellington, New Zealand: New Zealand Food Safety Authority 2005, 144-109.

132. Gray, M.A.; Harrins, A.; Centeno, J.A. The role of cadmium, zinc, and selenium in prostate disease. Metal contaminants in New Zealand: sources, treatments, and effects on ecology and human health 2005, 20, 393414.

133. Bernard, A. Cadmium \& its adverse effects on human health. Indian Journal of Medical Research. 2008, 128.

134. Duda-Chodak, A.; Blaszczyk, U. The impact of nickel on human health. Journal of Elementology. 2008, 13, 685-693.

135. Verma, R.K.; Sankhla, M.S.; Kumar, R. Mercury Contamination in Water \& Its Impact on Public Health. International Journal of Forensic Science 2018, 1, 72-78

136. Singh Sankhla, M.; Sharma, K.; Kumar, R. Heavy Metal Causing Neurotoxicity in Human Health. International Journal of Innovative Research in Science, Engineering and Technology 2017, 6, 7721-7726.

137. Singh Sankhla, M.; Mayurikumari; Nandan, M.; Kumar, R.; Agrawal, P.; Kumari, M. Heavy Metal Contamination in Soil and their Toxic Effect on Human Health: A Review Study. International Journal of All Research Education and Scientific Methods (IJARESM) 2016, 4, 13-19.

138. Arora, N.; Jaiswal, K.K.; Kumar, V.; Vlaskin, M.S.; Nanda, M.; Pruthi, V.; Chauhan, P.K. Small-scale phyco-mitigation of raw urban wastewater integrated with biodiesel production and its utilization for aquaculture. Bioresource Technology 2020, 297, https://doi.org/10.1016/j.biortech.2019.122489.

139. Ishikawa, Y.; Nakagawa, K.; Satoh, Y.; Kitagawa, T.; Sugano, H.; Hirano, T.; Tsuchiya, E. Characteristics of chromate workers' cancers, chromium lung deposition and precancerous bronchial lesions: an autopsy study. British Journal of Cancer 1994, 70, 160-166, https://doi.org/10.1038/bjc.1994.268.

140. Chen, Y.; Yu, W.; Zheng, R.; Li, J.-Y.; Zhang, L.; Wang, Q.; Yin, J.; Jin, L. Magnetic activated carbon (MAC) mitigates contaminant bioavailability in farm pond sediment and dietary risks in aquaculture products. Science of The Total Environment 2020, 736, https://doi.org/10.1016/j.scitotenv.2020.139185.

141. Guo, C.; Chen, Y.; Xia, W.; Qu, X.; Yuan, H.; Xie, S.; Lin, L.-S. Eutrophication and heavy metal pollution patterns in the water suppling lakes of China's south-to-north water diversion project. Science of The Total Environment 2020, 711, https://doi.org/10.1016/j.scitotenv.2019.134543.

142. Javed, M.; Usmani, N. Accumulation of heavy metals in fishes: a human health concern. International journal of environmental sciences 2011, 2, 659-670.

143. Weatherley, A.H.; Lake, P.S.; Rogers, S.C. Zinc Pollution and the Ecology of the Freshwater Environment. John Wiley \& Sons 1980, 10016, 337-418.

144. Karikari, A.Y.; Asmah, R.; Anku, W.W.; Amisah, S.; Agbo, N.W.; Telfer, T.C.; Ross, L.G. Heavy metal concentrations and sediment quality of a cage farm on Lake Volta, Ghana. Aquaculture Research 2020, 51, 2041-2051, https://doi.org/10.1111/are.14555. 